\title{
MODELLING THE EVOLUTION OF THE ARCHAEOLOGICAL WORKS DEVELOPED IN QUBBET EL-HAWA (ASWAN, EGYPT)
}

\author{
J. L. Pérez-García ${ }^{1}$, A. T. Mozas-Calvache ${ }^{1}$, J. M. Gómez-López ${ }^{1}$, A. Jiménez-Serrano² \\ ${ }^{1}$ Dept. Ingeniería Cartográfica, Geodésica y Fotogrametría, University of Jaén, 23071 Jaén, Spain - (jlperez, antmozas, \\ jglopez)@ujaen.es \\ ${ }^{2}$ Dept. Antropología, Geografía e Historia, University of Jaén, 23071 Jaén, Spain - ajiserra@ujaen.es
}

Commission II, WG II/8

KEY WORDS: Close Range Photogrammetry, TLS, 3D model, Egyptian tombs, Archaeology.

\begin{abstract}
:
This study describes the methodology carried out and the main results achieved when using photogrammetry and Terrestrial Laser Scanning (TLS) to obtain 3D models of the evolution of archaeological works in Egyptian tombs. More concretely, the study was performed in the exterior zone of the QH34 set of tombs located in the necropolis of Qubbet el-Hawa (Aswan, Egypt). The necropolis is composed of tens of rock-cut tombs located in a medium-size hill situated on a bank of the Nile River. The QH34 zone concentrates a great quantity of tombs from several periods of ancient Egypt. The area of study is situated on a horizontal platform of the terrain of about $300 \mathrm{~m}^{2}$. Thanks to the particular geology of this zone, with a fracture that caused the collapse of part of the rocks, much of these tombs have remained intact because the remains of the collapsed terrain hid their entrances. The archaeological works were carried out during two periods (2018 and 2019 campaigns). The main goal of this study was to model the evolution of these works using several geomatic techniques and obtaining several 3D models of the terrain and burial elements to document the previous, intermediate and final status and to analyse the archaeological works undertaken. In addition, a reduced time was demanded for the acquisition of data. The methodology developed has demonstrated its viability for performing multi-temporal studies in order to document the evolution of the excavation, providing a wide and reliable set of geomatic products.
\end{abstract}

\section{INTRODUCTION}

The development of geomatic techniques during the last decades has allowed the improvement of the graphical documentation of archaeological sites. This evolution has eased both the acquisition and the processing of data, allowing the application of these techniques even by non-professional users in simple circumstances. In this context, several techniques based on Close Range Photogrammetry (CRP), for example using low-cost cameras (Ogleby et al., 1999; Celikoyan, 2003; Cardenal et al., 2004; Chandler et al., 2005; Fangi, 2007; Covas et al., 2015; Fiorillo et al., 2016; Barazzetti et al., 2017a), and Terrestrial Laser Scanning (TLS) (Beraldin et al., 2000), have been widely applied. Among other products, CRP allows us to obtain point clouds from images, which can be used to obtain 3D models, while TLS allows us to capture this information directly from scanning stations.

The use of CRP to document archaeological sites supposes an option to consider in cases where a low-cost technique must be used or a high-quality realistic texture of the structure is demanded. However, the difficulties involved with the acquisition of photographs in complex structures conditioned the use of this technique because of the necessity to cover the entire object from several points of view, guaranteeing homogeneous illumination conditions. In addition, the presence of narrow spaces or occlusions could increase the quantity of photographs needed to cover the structure using normal focal lenses mounted in non-metric cameras. So some alternative procedures, such as the use of wide angle lens (Gómez-Lahoz, González-Aguilera, 2009; Mozas et al., 2012; Martínez et al., 2013; Fiorillo et al., 2016), fisheye lens (Boulianne et al., 1997; Kedzierski, Waczykowski, 2007; Georgantas et al., 2012; Covas et al., 2015; Perfetti et al. 2017; Barazzetti et al., 2017b) and 360 degrees cameras (Pérez-Ramos, Robleda-Prieto, 2016; Kossieris et al., 2017; Mandelli et al., 2017; Barazzetti et al., 2017a; Fangi et al., 2018; Cantatore et al. 2020; Bertellini et al., 2019) were implemented in order to reduce the quantity of images needed to cover the object. The use of Remotely Piloted Aircraft Systems (RPAS) (Colomina, Molina, 2014; Nex, Remondino, 2014; Campana, 2017) and masts (Georgopoulos, 1999; Mozas-Calvache et al., 2012; Martínez et al. 2013; Ortiz et al., 2013; Blockley, Morandi, 2015; Martínez et al., 2015; Pérez et al., 2019; Mozas-Calvache et al., 2019) to lift cameras supposes a useful alternative to photographs acquired from the ground because of the improvement of the coverage of the object (usually on the terrain) and the reduction of the occlusions (e.g. those caused by the presence of vertical walls). The development of these platforms for elevating sensors has also been expanded, allowing the obtaining of 3D models and cartography of archaeological sites easily. In addition to the improvements in sensors and hardware, the development of current processing algorithms, such as Structure from Motion (Ullman, 1979; Koenderink, Van Doorn, 1991; Lowe, 2004; Szeliski, 2011) and MultiView Stereo (MVS) (Scharstein, Szeliski, 2002; Seitz et al., 2006; Szeliski, 2011; Furukawa, Hernández, 2015), which are implemented in several commercial applications (Agisoft Metashape, Colmap, VisualSFM, Bentley ContextCapture, Sure) (Brutto, Meli, 2012; Rothermel et al., 2012; McCarthy, 2014; Green et al., 2014), have also contributed to the general use of CRP in these types of studies. In this sense, Westoby et al. (2012) indicated that these aspects have contributed to the 'democratization' of photogrammetry.

The use of TLS to obtain 3D models of archaeological sites supposes a viable option to consider when this type of instrument is available (although scanners have been reduced in 
price during the latest years, they are still too expensive to be considered in any project yet). In the case of complex sites, TLS supposes an excellent and powerful method of collecting 3D data and creating accurate surface models (Remondino et al., 2011). The operation of several scanning stations allows us to tackle the difficulties caused by complex structures. Furthermore, the acquisition time is relatively low at each station and more effective if the capture does not consider the acquisition of HDR images. In these cases, the illumination conditions are not important. TLS has shown promising results, even in complex spaces and structures, as demonstrated by Fernández-Palacios et al. (2013), Nabil et al, (2013), Lima and Vergauwen (2018), Echeverria et al (2019) and Mozas et al. 2020 in several Egyptian tombs. The presence of narrow spaces or occlusions will suggest the addition of more scanning stations to cover the structure completely in contrast to the low increment of time required by each scan.

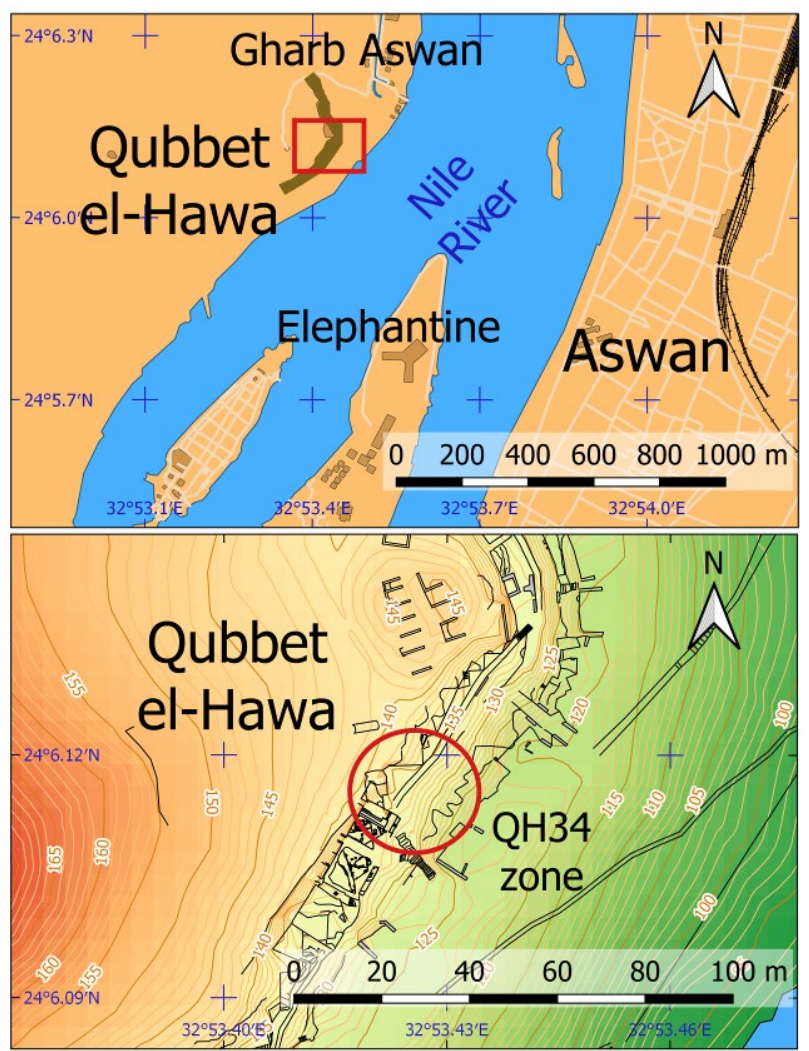

Figure 1. Location of the necropolis of Qubbet el-Hawa (Aswan, Egypt) and the QH34 zone.

A more detailed analysis of the advantages and problems of CRP and TLS in cultural heritage applications was conducted by Hassani et al. (2015). Several studies have shown that the integration of both techniques can improve results (Kadobayashi et al., 2004; Ahmon, 2004; Alshawabkeh, Haala, 2004; Guarnieri et al., 2006; Grussenmeyer et al., 2008; Lerma et al., 2010; Fernández-Palacios et al., 2013; Nabil et al., 2013; Lima, Vergauwen, 2018). In general, the integration of CRP and TLS has shown good results because it takes advantage of the particular characteristics of each technique. However, the selection of the technique to be used (or both), will depend on the object to be studied, the availability of instruments and other environmental circumstances. The selection should consider other variables of the project such as budget, location constraints, time needed for acquisition, final goal of the model, objectives, etc. (Lambers, Remondino, 2007). As an example,
TLS allows the fast acquisition of dense point clouds and photogrammetry provides more realistic textures and usually supposes the best option to generate other products (e.g. orthoimages). So a combination of the two methods could be interesting in various cases (Georgantas et al., 2012). In the case of the archaeological sites of Egypt we must consider other aspects, such as the availability of instruments, permits and other logistical issues, when selecting the geomatic technique to be applied.

Multi-temporal 3D modelling of archaeological sites allows the obtaining of $3 \mathrm{D}$ documentation for all stages of the excavation/intervention process instead of the usual documentation based on the final status of a site. However, the progress of excavation is especially interesting because in many cases the architecture of the site has been modified several times in the past and some of these phases have to be removed during the excavation work or can disappear due to unexpected events (e.g. collapses) (Koistinen, 2004). In addition, the 3D documentation of the archaeological process is especially important when archaeological works are discontinuous, as usually happens in the case of missions in Egypt. Using this documentation, different researchers can access easily (and remotely) to a reliable media to contrast the evolution of the archaeological works during the years. The obtaining of geomatic products, such as the 3D models, allows us to perform volumetric comparisons between times (e.g. between the initial and final status of an excavation). Other derived products, such as sections, digital models, orthoimages, etc., are also important to support the work of other researches. The combination of digital models and direct observations of the excavations results must operate with the aim of improving the comprehension and preservation of information for the documentation purposes (Chiabrando et al., 2017). Independently of the geomatic technique used at each stage, the products obtained must be comparable. Therefore, the use of a common reference system is fundamental in these types of studies.

In this study we describe a multi-temporal modelling of an archaeological excavation. More specifically, we have applied several geomatic techniques in order to obtain the $3 \mathrm{D}$ documentation of the QH34 zone in the Necropolis of Qubbet el Hawa in Aswan (Egypt) (Figure 1). The main goal has been to model the evolution of the archaeological works, mainly carried out during two periods (2018 and 2019), obtaining several 3D models of the terrain and burial elements. This documentation can be used to describe the previous, intermediate and final stages of the archaeological works carried out in this zone.

\subsection{Description of the QH34 funerary zone}

The original use of Qubbet el-Hawa as a necropolis dates back to the mid-6th Dynasty, around the reign of Pepy I (Edel, 2008). From that moment to the end of the Late 12th Dynasty the governors, the members of their households and their officials were buried in rock-hewn tombs in Qubbet el-Hawa. The monumentality of these tombs depends on the social and political position of the people buried in them. Thus, the largest tombs were constructed for the governors and their closest circle, while lower officials show smaller tombs.

Concerning the location of the tombs, we have observed (Jiménez-Serrano, 2021) that the governors' tombs were situated coinciding with the best rock strata, which was situated at a height of 130 meters above sea level. Moreover, these tombs were situated on the Northern-east side of the hill, while the secondary officials constructed their tombs on the Southeastern slope of Qubbet el-Hawa. However, since the reign of Amenmehat II $\left(1878-1843^{+3}\right)$ (Hornung et al., 2006), the 
Northern-east side of the hill lacked the space for grand new funerary complexes with an orientation towards the East, as all the tombs had. But there remained an area at the same altitude of the hill of nearly 75 meters long between QH30b and $\mathrm{QH} 34 \mathrm{a}$, which was probably intentionally left unoccupied to differentiate the cemetery of the governors from the burial ground of their highest officials, which extended from the $\mathrm{QH} 30 \mathrm{~b}$ to the South.

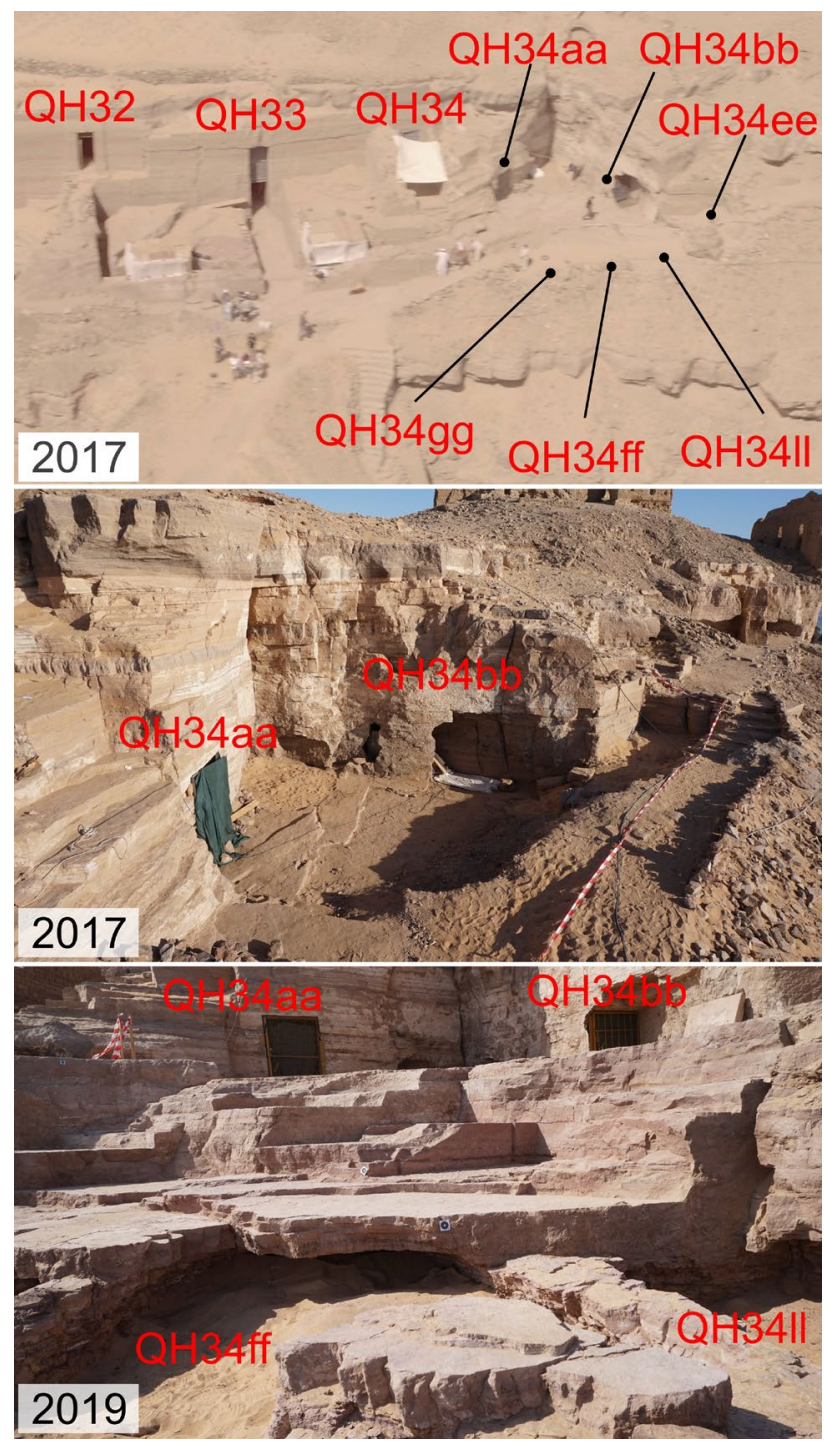

Figure 2. Views of the QH34 zone in 2017 and 2019.

The Governor Khema, who was governor under Amenmehat II, was responsible for the construction of the earliest monumental tomb (QH32) in this area (Martínez-Hermoso et al., 2018). The succeeding governors constructed their funerary complexes around Khema's tomb (QH31, Sarenput II, Khema's son, and QH33, Heqaib-Ankh (?) and Heqaib III, Khema's grandson's) or in its vicinity (QH30, Heqaib II). Immediately to the North of the funerary complex of this group, QH33, four smaller tombs were constructed. The chronology of these tombs coincides with the construction of the grand funerary complexes QH31 and QH33, dated between the reigns of Senwosret II (1845-1837) and Amenemhat III (1818-1773) (Hornung et al., 2006). These tombs were catalogued as QH34 and QH34aa, QH34bb and QH34ee (Jiménez-Serrano, Sánchez-León, 2019). The funerary equipment found in the interior of these tombs have permitted us to identify some of the occupants, who were members of the elite of Elephantine. Thus, it is possible to conclude that in the grand funerary complexes $(\mathrm{QH} 30, \mathrm{QH} 31$, QH32 and QH33) were buried the governors of Elephantine and their closest circle under the reigns of Amenemhat II to Amenemhat III, while the smaller tombs were occupied by "secondary members" of the ruling household of Elephantine. Therefore, the QH34 zone concentrates a great quantity of tombs from several periods of ancient Egypt.

Nowadays, the QH34 zone is characterized by a cut in the slope caused by a collapse of part of the hill. The zone is situated on a horizontal platform of the terrain of about $300 \mathrm{~m} 2$ (Figure 2), which contrasts with the slopes of the hill. Probably this collapse, caused in the past, had as a consequence the discovering of several intact tombs because the material provided by the landslide had hidden those funerary sites for centuries. Currently, the area of the QH34 zone is featured by a great natural wall caused by the rock collapse, which generates a horizontal platform where several tombs of different periods of ancient Egypt were distributed (Figure 2).

The QH34 zone (Figure 2) has been excavated during recent years by the team of the Qubbet el-Hawa Project of the University of Jaén (Spain). During the archaeological works a geomatic study of the structures was performed based on CRP and TLS from the original status, with a certain layer of sand covering the terrain and the interior of the tombs, to the final excavation when the rock basis was achieved and several intact tombs were discovered (Figure 2).

\section{METHODOLOGY AND APPLICATION}

The methodology developed in this study was based on the characteristics of the zone and the objectives of the project. Firstly, a medium-size zone that included a rock wall up to 7 metres high that appeared after the collapse of part of the slope. Secondly, the 3D documentation demanded had to include real textures of the terrain. Thirdly, the availability of instruments and platforms at each time, which highly conditioned the selection of the technique to use. Finally, in this site we must highlight the coincidence of other works, which limited the time available for data acquisition (several hours) and other difficulties due to the presence of workers and tourists. There was no possibility of repeating acquisition works, so the data capture had to guarantee the completeness of the information. We decided to use several techniques when it was possible.

These circumstances justified the decision of using photogrammetry (CRP), supported in some stages with TLS (Figure 3). Considering the presence of a rock wall and several vertical walls (Figure 2), we decided to lift a camera to avoid occlusions and to reduce the number of photographs taken to cover the scene. However, the authorities did not allow us to use RPAS. The exclusive use of photographs taken from the ground would generate a large quantity of photographs covering the object and the possible appearance of multiple occlusions caused by the morphology of the terrain. This problem was solved by using a light mast with a length up to 6 metres to lift the camera (several one-metre poles composed this mast). At the extreme of the mast, we mounted a conventional non-metric camera (Sony alfa 5000) with tilts of $0^{\circ}-45^{\circ}$ and remotely controlled. The system was supported and easily moved by two operators. Using this system, we developed the methodology described by Pérez-García et al. (2018) to capture images based on several stations of the mast. At each station eight photographs were acquired by turning the system (mast and camera) $45^{\circ}$ to take each photograph. However, this approach caused divergent images. The recommendations of the 
International Committee of Architectural Photogrammetry (CIPA) for planning architectural photogrammetric projects using non-metric cameras (known as the $3 \times 3$ rules) include multiple photographic all-around coverage which involves taking a ring of images all around the object, overlapping each other by more than $50 \%$. This supposes the obtaining of convergent photographs which cover the entire object (Waldhäusl, Ogleby, 1994). In order to resolve this issue (divergence), we used images obtained from several stations of the mast. So the stations were distributed over the zone considering the coverage of the photographs and the necessity of capturing the object with several convergent and normal-case images.

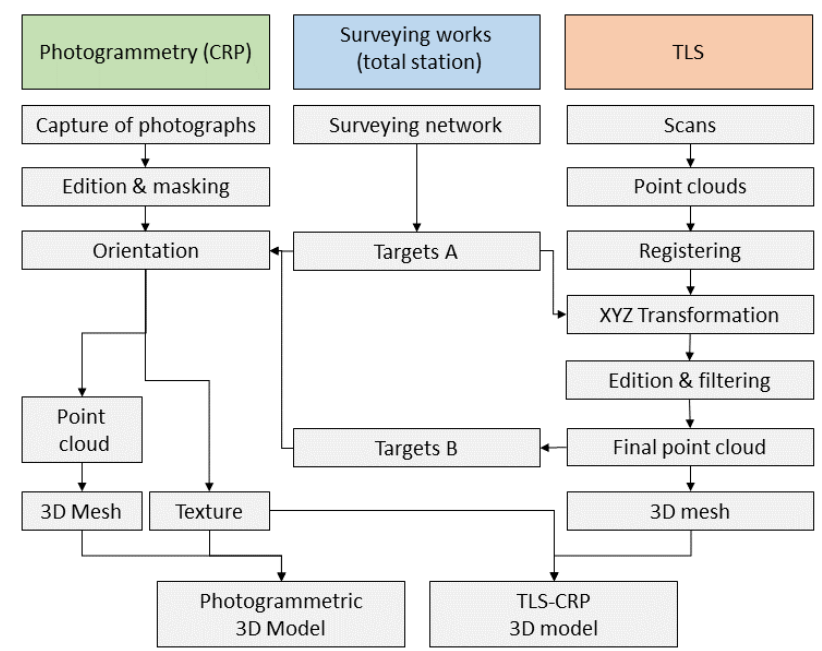

Figure 3. Methodology.

The coverage of each photograph depends on several parameters, such as the terrain topography, the presence of occlusions, the camera parameters, the height of the mast, the inclination of the camera, etc. So a theoretical distance value between stations was calculated using these parameters and we added a wide security margin. In the field we also used a remote viewer controlled by an operator to guarantee full coverage of the photographs and avoid occlusions. In addition to the photographs obtained using the mast, we also took other photographs from the ground to complete the coverage of the object under study (e.g. Figure 4a). After the capture of photographs, an edition and masking stage was undertaken in order to avoid images or some parts of them which were not desirable to process. The Agisoft Metashape software was used to process all photogrammetric projects (including orientation, the obtaining of point clouds, meshes and textures, and obtaining final products). The accuracy achieved during the orientation procedure was at centimetre level.

In addition to the CRP survey, the methodology (Figure 3 ) also includes the obtaining of point clouds from TLS. Unfortunately, this survey was only able to be implemented when the instruments were available (intermediate and final stages). The goal was to support the 3D model obtained using CRP, checking its geometrical aspect. Therefore, we used a TLS (Faro Focus X130) (Figure 4b). The location of the scan stations supposes a critical step in the implementation of TLS surveys in archaeological sites. The main aspects to be considered are the necessity of obtaining a complete coverage of the object and the existence of common overlapped zones between adjacent stations in order to ease registering procedures of the scans. The registration of the point clouds acquired using TLS was carried out using Faro Scene software. After that, an XYZ transformation was carried out to refer the final point cloud to the project reference system. This point cloud was edited, removing points from non-desirable objects and filtered with a certain distance between points in order to obtain a homogeneous point cloud. The final point cloud was used to obtain a 3D mesh using the Poisson Mesh Reconstruction described by Kazhdan et al. (2006).

The general application of the methodology was developed twice. First, previously to the archaeological works and second, after these works. In addition, several additional photogrammetric studies were applied to particular zones during the archaeological works in order to model the status of these stages. As an example, the QH34ff and QH34ll tombs were studied previously to their discovery, after the cleaning process (several human skeletons and crocodile mummies were modelled) (Figure 4b) and after the extraction of these elements (final status). This supposes a complete study of the archaeological works developed in these tombs.

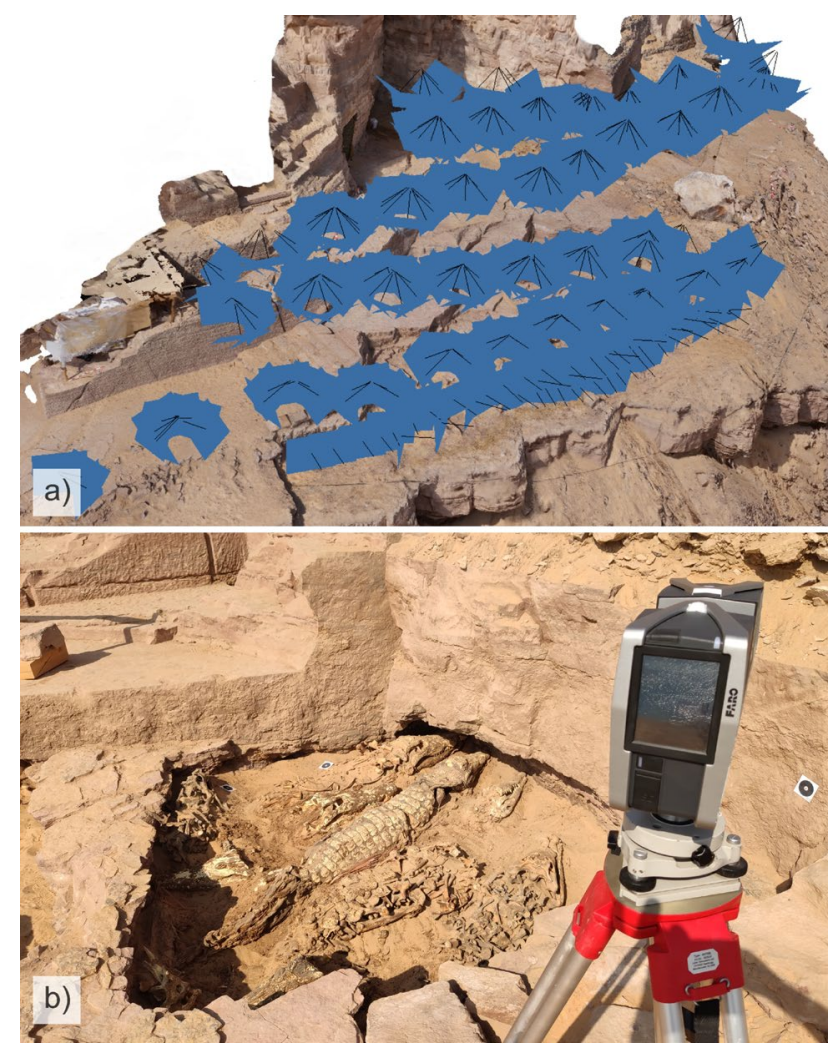

Figure 4. Application: a) Location of photographs (2019); b) Scanning of the QH34ll tomb including crocodile mummies.

All photogrammetric and TLS studies were referred to the same reference system in order to ease the comparison and integration of their products. This stage included the distribution of several Ground Control Points (GCPs) with known coordinates in order to orient photographs and point clouds from TLS within a defined reference system. The coordinates were obtained from a surveying network (previously measured using GNSS) using a total station. This process, which is very important in any geomatic study for obtaining a graphical documentation referred to a defined system, is fundamental when we are performing multi-temporal studies because of the necessity of comparing models from data captured at different times. The selection and location of targets to implement the GCPs must guarantee several aspects, such as the selection of a large enough quantity and good distribution of targets over the scene, the determination of targets of an appropriate size in order to obtain a correct identification of the 
GCP in several photographs (taken from variable distances), etc. Alternative targets were also used to check the orientations of photographs and transformations of point clouds. In the case of the last campaign, the number of targets obtained with the total station was reduced in order to minimize the acquisition time (working area). Therefore, we used additional targets obtained from the TLS point cloud after it had been transformed to a global reference system. We must highlight the advantage of using this combined methodology to reduce the volume of GCPs acquired using total station, with a great reduction of acquisition time.
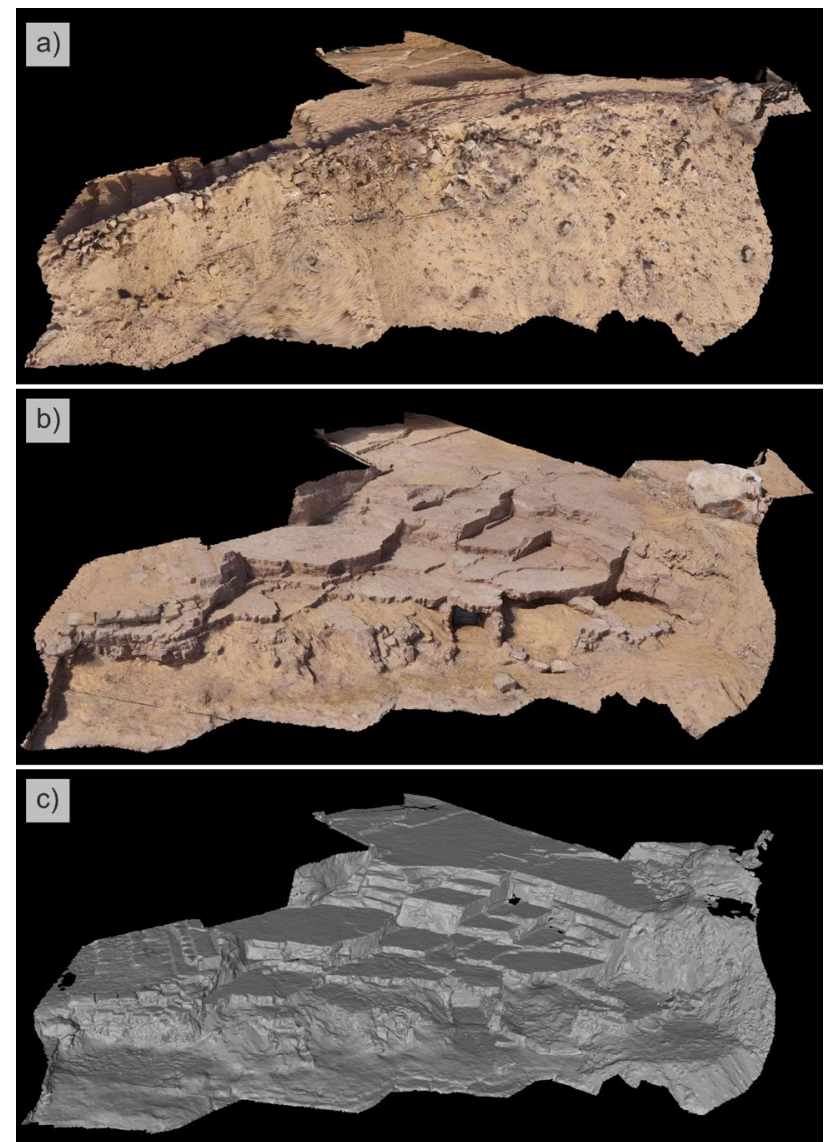

Figure 5. 3D models obtained: a) 2017 from CRP; b) 2019 from CRP; c) 2019 from TLS.

\section{RESULTS}

The results included 3D models both from photogrammetry and from TLS of several excavation stages and zones. In addition, other derived products were obtained, such as Digital Elevation Models (DEM), ground orthoimages, etc. Considering the complete zone, we obtained a 3D model with real texture of the initial status (from CRP) (Figure 5a), a 3D model with real texture of the final status (from CRP) (Figure 5b) and another 3D mesh without real texture (from TLS) (Figure 5c). This 3D mesh has been used to contrast the photogrammetric final model (Figure 6b) but can also be used as a final 3D model by adding texture obtained from CRP. A comparison of the models has been carried out using the Maptek Point Studio and CloudCompare software. Firstly, the comparison between the initial and final status of the excavation has revealed a terrain movement (sand) of about $114 \mathrm{~m}^{3}$ (Figure 6a). At some points there were more than 2.5 metres of excavation.

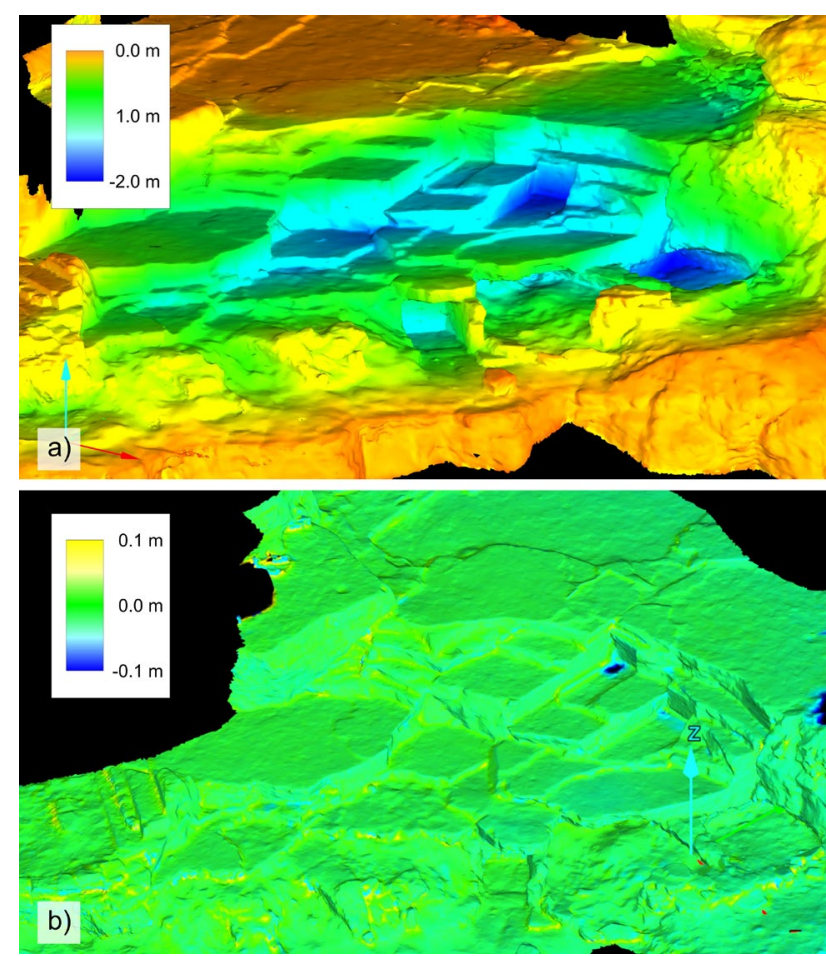

Figure 6. Comparison between 3D models: a) CRP (2017) vs CRP (2019); b) CRP (2019) vs TLS (2019).

Secondly, the comparison between the model obtained in 2019 based on CRP and that obtained using TLS has shown low discrepancies (Figure 6b), with an average value of about 0.003 $\mathrm{m}$ and an RMSE value of 0.011 metres. We used a sample of more than 142000 points to compare both models. The discrepancies are mainly based on the interpolation performed in small zones without data, the different software used for triangulation and the usual smoothness of the models obtained using CRP with respect to TLS. However the results obtained demonstrate that both meshes are quite similar (even the mean value of the differences is lower than data resolution).

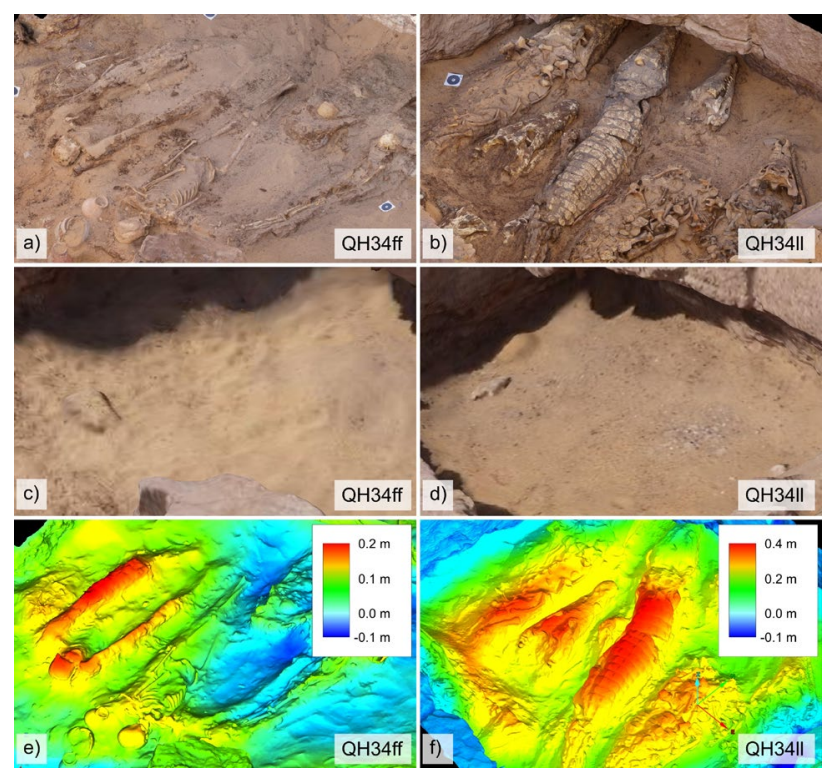

Figure 7. 3D models: a) $\&$ b) previously to the excavation; c) \& d) after the excavation; e) \& f) Comparison between both periods. 
In addition to the study of the complete zone, we also obtained several 3D models (Figure 7a and Figure 7b) and orthoimages of two burial structures (QH34ff and QH3411), whose archaeological process was subsequently modelled (including the study previous to and after the extraction of the burial elements). The 3D models including the burial elements (Figure $7 \mathrm{a}$ and Figure $7 \mathrm{~b}$ ) and the final status (cleaned) (Figure $7 \mathrm{c}$ and Figure 7d) were also compared (Figure 7e and Figure 7f), showing elevations caused by the objects of up to 0.39 metres with respect to the model of the final status. The special importance of the remains discovered in these burial sites (some skeletons, ritual objects and crocodile mummies) demanded an additional documentation based on orthoimages in order to obtain a realistic plan view of these spaces. These orthoimages were created using a spatial resolution of 5 millimetres in order to display these objects with a great level of detail. Other products, such as DEMs, were also included in the graphical documentation of these tombs.

\section{CONCLUSIONS}

The image acquisition procedure developed in this study has demonstrated its efficiency in medium-sized archaeological areas when the RPAS are not allowed. The photogrammetric products obtained in this study are accurate enough to document the evolution of the archaeological works (all stages). In this sense, the use of a common reference system is fundamental when the archaeological works are undertaken during various campaigns distributed over several years in order to integrate and compare all results. Despite the interruption of the archaeological works after each step of excavation, the acquisition procedures did not affect these works much (1-2 hours). In contrast, archaeologists have obtained reliable 3D documentation to aid in analysing their works including excavation areas, the volume of material removed (Figure 6a), the archaeological evolution, etc. The extraction process of several burial elements discovered in several tombs was also modelled (Figure 7). In these cases, the 3D models obtained have allowed the documentation of all stages with a great level of detail. We must consider that those burial elements were moved from the original location, therefore this documentation supposes the only geometrical documentation of these elements in their original environment.

Considering the necessity of a fast acquisition of data, the methodology developed has demonstrated its efficiency. The use of TLS to support data obtained using photogrammetry is important to contrast the geometry obtained with CRP and to fill those gaps produced by occlusions in images, but also to reduce the number of targets measured with total station. This aspect is important in reducing the time spent on field works and as consequence, the effect on other works.

The 3D models obtained have demonstrated their viability as a reliable product for documenting graphically an archaeological site. This product can be easily consulted by other researchers such as architects and geologists, allowing them to access a model of reality everywhere and at every time. In this sense, these professionals have used 3D models to helping them to analyse the construction procedures and the morphology of this zone from the past, etc.

The multi-temporal 3D documentation of the archaeological works developed in this study has been the first analysis of this type implemented in this project. In future, the methodology proposed in this study will be implemented in other zones, modelling all archaeological works to be realized.

\section{ACKNOWLEDGEMENTS}

The present paper is the result of research carried out with funds provided by the MINECO (Government of Spain), as part of the project HAR2016-75533-P "Excavación, estudio histórico y conservación de las tumbas del Reino Medio de la necrópolis de Qubbet el-Hawa (Asuán, Egipto)", as well as private institutions such as Fundación Gaselec, Fundación Palarq, Asociación Española de Egiptología and Cátedra de Egiptología de la Universidad de Jaén.

\section{REFERENCES}

Ahmon, J. 2004. The Application of Short-Range 3D Laser Scanning for Archaeological Replica Production: The Egyptian Tomb of Seti I. Photogramm. Rec., 19(106), 111-127.

Alshawabkeh, Y., Haala, N., 2004. Integration of digital photogrammetry and laser scanning for heritage documentation. Int. Arch. Photogramm. Remote Sens. Spatial Inf. Sci., 35, B5.

Barazzetti, L., Previtali, M., Roncoroni, F., 2017a. 3D Modelling with the Samsung Gear 360. Int. Arch. Photogramm. Remote Sens. Spatial Inf. Sci., XLII-2-W3, 85-90.

Barazzetti, L., Previtali, M., Roncoroni, F., 2017b. Fisheye lenses for 3D modeling: evaluations and considerations. Int. Arch. Photogramm. Remote Sens. Spatial Inf. Sci., XLII-2/W3, 79-84.

Beraldin, J. A., Blais, F., Boulanger, P., Cournoyer, L., Domey, J., El-Hakim, S. F., G. Godin, M. Rioux, Taylor, J., 2000. Real world modelling through high resolution digital 3D imaging of objects and structures ISPRS J. Photogramm., 55(4), 230-250.

Bertellini, B., Gottardi, C., Vernier, P., 2019. 3D survey techniques for the conservation and the enhancement of a Venetian historical architecture. Applied Geomatics, 1-16.

Blockley, P., Morandi, S., 2015. The recording of two late Roman towers, Archaeological Museum, Milan 3D documentation and study using image-based modelling. In Digital Heritage 2015, IEEE, Granada, Spain, 103-106.

Boulianne, M., Nolette, C., Agnard, J. P., Brindamour, M., 1997. Hemispherical photographs used for mapping confined spaces. Photogramm. Eng. Remote Sensing, 63(9), 1103-1108.

Brutto, M.L., Meli, P., 2012. Computer vision tools for 3D modelling in archaeology. International Journal of Heritage in the Digital Era, 1, 1-6.

Campana, S., 2017. Drones in Archaeology. State-of-the-art and Future Perspectives. Archaeol. Prospect., 24(4), 275-296.

Cantatore, E., Lasorella, M., Fatiguso, F., 2020. Virtual reality to support technical knowledge in cultural heritage. The case study of cryptoporticus in the archaeological site of Egnatia (Italy). Int. Arch. Photogramm. Remote Sens. Spatial Inf. Sci., 44, 465-472.

Cardenal, J., Mata, E., Castro, P., Delgado, J., Hernandez, M.A., Pérez, J.L., Ramos, M., Torres, M., 2004. Evaluation of a digital non metric camera (Canon D30) for the photogrammetric recording of historical buildings. Int. Arch. 
Photogramm. Remote Sens. Spatial Inf. Sci., XXXV-B5, 564569.

Celikoyan, T.M., Altan, M.O., Kemper, G., Toz, G., 2003. Calibrating and using an olympus camera for balloon photogrammetry. In Proc. XIXth International Syposium-CIPA 2003, Antalya, Turkey, 380-382.

Chandler, J.H., Fryer, J.G., Jack, A., 2005. Metric capabilities of low-cost digital cameras for close range surface measurement. Photogramm. Rec., 20(109), 12-26.

Chiabrando, F., Sammartano, G., Spanò, A., Semeraro, G., 2017. Multi-temporal images and 3D dense models for archaeological site monitoring in Hierapolis of Phrygia (TK). Archeologia e Calcolatori, 28(2), 469-484.

Colomina, I., Molina, P., 2014. Unmanned aerial systems for photogrammetry and remote sensing: A review. ISPRS J. Photogramm., 92, 79-97.

Covas, J., Ferreira, V., Mateus, L., 2015. 3D reconstruction with fisheye images strategies to survey complex heritage buildings. In Digital Heritage 2015., IEEE, Granada, Spain, 123-126.

Echeverría, E., Celis, F., Morales, A., da Casa, F., 2019. The Tomb of Ipi: 3D Documentation in a Middle Kingdom Theban Necropolis (Egypt, 2000 BCE). Int. Arch. Photogramm. Remote Sens. Spatial Inf. Sci., XLII-2/W9, 319-324.

Edel, E., 2008. Die Felsgräbernekropole der Qubbet el-Hawa bei Assuan. Architektur, Darstellungen, Texte, archäologischer Befund und Funde der Gräber QH24-QH209. In Seyfried, K. J., Vieler, G. (eds.). I. Abteilung, Band 1-3, Ferdinand Schöningh, Paderborn, Germany.

Fangi, G., 2007. The multi-image spherical panoramas as a tool for architectural survey. Int. Arch. Photogramm. Remote Sens. Spatial Inf. Sci., 36(5/C53): 311-316.

Fangi, G., Pierdicca, R., Sturari, M., Malinverni, E. S., 2018. Improving spherical photogrammetry using $360^{\circ}$ omni-cameras: use cases and new applications. Int. Arch. Photogramm. Remote Sens. Spatial Inf. Sci., 42(2), 331-337.

Fernández-Palacios, B.J., Rizzi, A., Remondino, F., 2013. Etruscans in 3D-Surveying and 3D modeling for a better access and understanding of heritage. Virtual archaeol. rev., 4(8), 8589.

Fiorillo, F., Limongiello, M., Fernández-Palacios, B.J., 2016. Testing GoPro for 3D model reconstruction in narrow spaces. Acta IMEKO, 5(2), 64-70.

Furukawa, Y., Hernández, C., 2015. Multi-view stereo: A tutorial. Found. Trends Comput. Graph. Vis., 9(1-2), 1-148.

Georgopoulos, A., Karras, G.E., Makris, G.N., 1999. The photogrammetric survey of a prehistoric site undergoing removal. Photogramm. Rec., 16(93), 443-456.

Georgantas, A., Brédif, M., Pierrot-Desseilligny, M., 2012. An accuracy assessment of automated photogrammetric techniques for 3D modelling of complex interiors. Int. Arch. Photogramm. Remote Sens. Spatial Inf. Sci., 39, 23-28.
Gómez-Lahoz, J.G., González-Aguilera, D., 2009. Recovering traditions in the digital era: the use of blimps for modelling the archaeological cultural heritage. J. Archaeol. Sci., 36, 100-109.

Green, S., Bevan, A., Shapland, M., 2014. A comparative assessment of structure from motion methods for archaeological research. J. Archaeol. Sci., 46, 173-181.

Guarnieri, A., Remondino, F., Vettore, A., 2006. Digital photogrammetry and TLS data fusion applied to Cultural Heritage 3D modeling. Int. Arch. Photogramm. Remote Sens. Spatial Inf. Sci., XXXVI-5.

Grussenmeyer, P., Landes, T., Voegtle, T. and Ringle, K., 2008. Comparison methods of terrestrial laser scanning, photogrammetry and tacheometry data for recording of cultural heritage buildings. Int. Arch. Photogramm. Remote Sens. Spatial Inf. Sci., XXXVII-B5, 213-218.

Hassani, F., Moser, M., Rampold, R., Wu, C., 2015. Documentation of cultural heritage; techniques, potentials, and constraints. Int. Arch. Photogramm. Remote Sens. Spatial Inf. Sci., 40(5), 207.

Hornung, E., Krauss, R., Warburton, D. A., 2006, Ancient Egyptian Chronology. Brill, Leiden-Boston, USA.

Jiménez-Serrano, A., Sánchez-León, J. C., 2019. Le Premier Nome du sud de l'Égypte au Moyen Empire, BAR International Series, Oxford, UK.

Jiménez-Serrano, A., 2021. The Social Organisation of a Funerary Space: Qubbet el-Hawa from the Old Kingdom to the First Intermediate Period. In Lange-Athinodorou, E. \& De Meyer, M. (eds.), Beyond Memphis. The Transition of the Late Old Kingdom to the First Intermediate Period as reflected in Provincial Cemeteries. Peeters, Leuven, Belgium. In Press.

Kadobayashi, R., Kochi, N., Otani, H., Furukawa, R., 2004. Comparison and evaluation of laser scanning and photogrammetry and their combined use for digital recording of cultural heritage. Int. Arch. Photogramm. Remote Sens. Spatial Inf. Sci., 35(5), 401-406.

Kazhdan, M., Bolitho, M., Hoppe, H., 2006. Poisson surface reconstruction. In Proceedings of the fourth Eurographics symposium on Geometry processing (Vol. 7), 61-70.

Kedzierski, M., Waczykowski, P., 2007. Fisheye lens camera system application to cultural heritage data acquisition. In $X X I$ International CIPA Symposium, CIPA, Athens, Greece.

Koenderink, J.J., Van Doorn, A.J., 1991. Affine structure from motion. J Opt. Soc. Am. A, 8(2), 377-385.

Koistinen, K., 2004. Multitemporal archaeological imagery to model the progress of excavation. Int. Arch. Photogramm. Remote Sens. Spatial Inf. Sci., XXXV, B5, 1006-1011.

Kossieris, S., Kourounioti, O., Agrafiotis, P., Georgopoulos, A., 2017. Developing a low-cost system for $3 \mathrm{~d}$ data acquisition. Int. Arch. Photogramm. Remote Sens. Spatial Inf. Sci., XLII-2/W8, 119-126.

Lambers, K., Remondino, F., 2007. Optical 3D measurement techniques in archaeology: recent developments and 
applications. In Proc. of the 35th International Conference on Computer Applications and Quantitative Methods in Archaeology, Berlin, Germany, 27-35.

Lerma, J.L., Navarro, S., Cabrelles, M., Villaverde, V., 2010. Terrestrial laser scanning and close range photogrammetry for 3D archaeological documentation: The Upper Palaeolithic Cave of Parpalló as a case study. J. Archaeol. Sci., 37 (3), 499-507.

Lima de, R., Vergauwen, M., 2018. From TLS Recoding to VR Environment for Documentation of the Governor's Tombs in Dayr al-Barsha, Egypt. In 2018 IEEE International Symposium on Mixed and Augmented Reality Adjunct (ISMAR-Adjunct), IEEE, Munich, Germany, 293-298.

Lowe, D.G., 2004. Distinctive image features from scaleinvariant keypoints. Int. J. Comput. Vision, 60(2), 91-110.

Mandelli, A., Fassi, F., Perfetti, L., and Polari, C., 2017. Testing different survey techniques to model architectonic narrow spaces, Int. Arch. Photogramm. Remote Sens. Spatial Inf. Sci., XLII-2/W5, 505-511.

Martínez, S., Ortiz, J., Gil, M.L., Rego, M.T., 2013. Recording complex structures using close range photogrammetry: The cathedral of Santiago de Compostela. Photogramm. Rec., 28(144), 375-395.

Martínez, S., Ortiz, J., Gil, M., 2015. Geometric documentation of historical pavements using automated digital photogrammetry and high-density reconstruction algorithms. $J$. Archaeol. Sci., 53, 1-11.

Martínez-Hermoso, J.A., Mellado-García, I., Martínez de Dios, J.L, Martínez-Hermoso, F., Espejo-Jiménez, A.M., JiménezSerrano, A., 2018. The construction of tomb group QH31 (Sarenput II) through QH33. Part I: The exterior of the funerary complexes, The Journal of Ancient Egyptian Architecture, 3, $25-44$

McCarthy, J., 2014. Multi-image photogrammetry as a practical tool for cultural heritage survey and community engagement. $J$. Archaeol. Sci., 43, 175-185.

Mozas-Calvache, A.T., Pérez-García, J.L., CardernalEscarcena, F.J., Delgado, J., Mata de Castro, E., 2012. Comparison of Low Altitude Photogrammetric Methods for Obtaining Dems and Orthoimages of Archaeological Sites. Int. Arch. Photogramm. Remote Sens. Spatial Inf. Sci., XXXIX-B5, 577-581.

Mozas-Calvache, A. T., Pérez-García, J. L., Barba-Colmenero, V., Jiménez-Serrano, A., 2019. Photogrammetric study of the Qubbet el-Hawa Coptic Church (Aswan, Egypt). ISPRS Ann. Photogramm. Remote Sens. Spatial Inf. Sci., IV-2/W6. 115-121

Mozas-Calvache, A. T., Pérez-García, J. L., Gómez-López, J. M., de Dios, J. M., Jiménez-Serrano, A., 2020. 3D models of the QH31, QH32 and QH33 Tombs in Qubbet El Hawa (Aswan, Egypt). Int. Arch. Photogramm. Remote Sens. Spatial Inf. Sci., 43, 1427-1434.

Nabil, M., Betrò, M., Metwallya, M.N., 2013. 3D reconstruction of ancient Egyptian rockcut tombs: the case of Midan 05. Int. Arch. Photogramm. Remote Sens. Spatial Inf. Sci., XL-5/W2, 443-447.
Nex, F., Remondino, F., 2014. UAV for 3D mapping applications: a review. Appl. Geomatics, 6(1), 1-15.

Ogleby, C.L., Papadaki, H., Robson, S., Shortis, M.R., 1999. Comparative camera calibrations of some "off the shelf" digital cameras suited to archaeological purposes. Int. Arch. Photogramm. Remote Sens. Spatial Inf. Sci., XXXII-5/W11, 6975.

Ortiz, J., Gil, M.L., Martínez, S., Rego, T., Meijide, G., 2013. Three-dimensional Modelling of Archaeological Sites Using Close-range Automatic Correlation Photogrammetry and Low-altitude Imagery. Archaeol. Prospect., 20(3), 205-217.

Pérez-García, J.L., Mozas-Calvache, A.T., Gómez-López, J.M., Jiménez-Serrano, A., 2018. Three-dimensional modelling of large archaeological sites using images obtained from masts. Application to Qubbet el-Hawa site (Aswan, Egypt). Archaeol. Prospect., 26 (2), 121-135.

Pérez-Ramos, A., Robleda-Prieto, G., 2016. Only image based for the $3 \mathrm{~d}$ metric survey of gothic structures by using frame cameras and panoramic cameras, Int. Arch. Photogramm. Remote Sens. Spatial Inf. Sci., XLI-B5, 363-370.

Perfetti, L., Polari, C., Fassi, F., 2017. Fisheye photogrammetry: tests and methodologies for the survey of narrow spaces. Int. Arch. Photogramm. Remote Sens. Spatial Inf. Sci., XLII-2/W3, 573-580.

Remondino, F., 2011. Heritage recording and 3D modeling with photogrammetry and 3D scanning. Remote Sens-Basel, 3(6), 1104-1138.

Rothermel, M., Wenzel, K., Fritsch, D., Haala, N., 2012. SURE: Photogrammetric surface reconstruction from imagery. In Proceedings LC3D Workshop, Berlin, Germany.

Scharstein, D., Szeliski, R., 2002. A taxonomy and evaluation of dense two-frame stereo correspondence algorithms. Int. J. Comput. Vision, 47(1-3), 7-42.

Seitz, S.M., Curless, B., Diebel, J., Scharstein, D., Szeliski, R., 2006. A comparison and evaluation of multi-view stereo reconstruction algorithms. In IEEE Computer Society Conference on Computer Vision and Pattern Recognition, IEEE, New York, USA, 519-528.

Szeliski, R., 2011. Computer Vision: Algorithms and Applications. Springer, London.

Ullman, S., 1979. The interpretation of structure from motion. Proc. Royal Soc. London B, 203, 405-426.

Waldhäusl, P., Ogleby, C.L., 1994. 3 x 3 rules for simple photogrammetric documentation of architecture. Int. Arch. Photogramm. Remote Sens., 30, 426-429.

Westoby, M.J., Brasington, J., Glasser, N.F., Hambrey, M.J., Reynolds, J.M., 2012. 'Structure-from-Motion' photogrammetry: A low-cost, effective tool for geoscience applications. Geomorphology, 179, 300-314. 